\title{
analøg days
}





\section{analog days}

THE INVENTION

ANDIMPACT OF THE

MOOG SYNTHESIZER

Trevor Pinch and Frank Trocco

HARVARD UNIVERSITY PRESS

Cambridge, Massachusetts, and London, England 


\section{For Annika and Benika and \\ For Emmett and Zaela}

Copyright (C) 2002 by the President and Fellows of Harvard College

ALL RIGHTS RESERVED

Printed in the United States of America

First Harvard University Press paperback edition, 2004

Library of Congress Cataloging-in-Publication Data

Pinch, T. J. (Trevor J.)

Analog days : the invention and impact of the Moog synthesizer /

Trevor Pinch and Frank Trocco,

$$
\text { p. } \mathrm{cm} \text {. }
$$

Includes bibliographical references and index.

$$
\text { Discography: p. }
$$

ISBN o-674-00889-8 (cloth)

ISBN o-674-01617-3 (pbk.)

1. Moog synthesizer. I. Trocco, Frank. II. Title.

$$
\begin{array}{cc}
\text { MLiog2 .P56 } & 2002 \\
786.7^{\prime} 419-\mathrm{dc} 21 & 2002027257
\end{array}
$$

